\title{
Exposure of biofilms to meiofaunal copepods affects the larval settlement of Hydroides elegans (Polychaeta)
}

\author{
Hans-U. Dahms, Pei-Y. Qian* \\ Department of Biology, The Hong Kong University of Science and Technology, Coastal Marine Lab, Clear Water Bay, \\ Kowloon, Hong Kong SAR
}

\begin{abstract}
This study reports significant differences in larval settlement of the polychaete Hydroides elegans (Haswell, 1883) on biofilms treated either by different densities of live harpacticoid copepods or conditioned by particulate organic material (POM) retrieved from harpacticoid copepod cultures. The copepods used in this study were the facultatively predatory Tisbe japonica and the detritivorous Nitocra spinipes. The resulting biofilms covering experimental surfaces exhibited differences in bacterial abundances, bacterial community profiles and bioactivity, as evidenced by differential attractivity provided as percentages of larval settlement. The density of settled larvae decreased on biofilms modified by increasing numbers of copepods. The highest bacterial densities $\left(16085 \pm 915\right.$ cells $\left.\mathrm{mm}^{-2}\right)$ were found on natural biofilms conditioned with POM from cultures of $T$. japonica. The lowest bacterial densities $\left(4020 \pm 765\right.$ cells $\left.\mathrm{mm}^{-2}\right)$ were found on biofilms grown in the presence of the highest numbers of live T. japonica. Spearman-rank correlation results revealed a positive trend between increasing bacterial densities and larval settlement. Increasing copepod abundances were correlated with reduced bacterial densities and caused changes in the bacterial community profiles, which were identified by terminal restriction fragment analyses. Changes in microbial biofilms due to the conditioning effects of copepods or their remains/exudates are assumed to be responsible for differential larval settlement. Hence, the present laboratory study demonstrates that effects of predators can be mediated by biofilms and affect larval settlement indirectly.
\end{abstract}

KEY WORDS: Hydroides elegans · Interference · Disturbance • Biofilm • Bioturbation · Biocommunication $\cdot$ Larval settlement $\cdot$ Bacterial communities $\cdot$ T-RFLP

Resale or republication not permitted without written consent of the publisher

\section{INTRODUCTION}

The abundance and distribution of larvae, the factors regulating larval mortality, and larval site-selection behavior during settlement processes play important roles in the establishment of macrofaunal communities (Zajac \& Whitlatch 2003). This is particularly true in the critical period of active site selection of invertebrate larvae before settlement (Pawlik 1992). Variations in larval site selection may, in turn, have important impacts on the structure of benthic communities and the population dynamics of taxa (Underwood \& Fairweather 1989).
Several studies demonstrate that larvae choose their settlement sites being motivated by internal mechanisms and guided by various external factors (Steinberg et al. 2002). They thereby increase their chances for post-settlement survival and growth (Raimondi \& Keough 1990). If they do not find an appropriate settlement site, larvae may delay settlement. The ability of larvae to delay settlement varies considerably among larval taxa and environmental conditions (Pechenik 1990). The 'desperate larvae hypothesis' assumes that settlement will eventually take place before a point of no return is reached, even if the habitat is not optimal (see Toonen \& Pawlik 2001, Marshall \& Keough 2003). 
Patterns and processes of larval settlement are influenced by extrinsic factors such as chemical settlement cues (e.g. Pawlik 1992), food (e.g. Qiu \& Qian 1997), or disturbance-induced mortality of larvae due to physical, chemical, or biological causes (Rumrill 1990). Biological disturbances, such as competition, the effects of parasites and pathogens, or predation, are important factors to determine the spatial and temporal variation in the community structure of marine invertebrates (see Swain et al. 1998 for an overview) and the dynamics of their populations (Zajac \& Whitlatch 2003). Biological disturbance can be caused by predation (Rumrill 1990), classical exploitation competition (Young \& Chia 1981), or behavioral and/or chemical deterrence interference competition (McClintock \& Baker 2001). These factors cause differential larval settlement (Delany et al. 2003), and influence the abundance and distribution of benthic taxa as well as the community structure of macroinvertebrate associations (Zajac \& Whitlatch 2003). As for predators, their abundances and taxonomic composition fluctuate spatially and temporally in the field, and the vulnerability of settling larvae to predators may change ontogenetically (cf. Morgan 1995).

Larval mortality due to predation can be substantial (Rumrill 1990). This is inferred not only from the high numbers of larvae produced by several taxa, with only a minor proportion reaching maturity, but also from high fluctuations in settlement events (Underwood \& Fairweather 1989). The effects of predation, however, reach beyond physical elimination. Next to lethal effects, predators may cause sublethal effects (Nakaoka 2000), particularly during the critical time interval of settlement and metamorphosis. Predators may cause 'irritational' disturbance simply by their presence, or by the indirect communication of their presence. Irritation may result in subsequent delays of attachment which would eventually cause the failure of a settlement attempt, or the settlement of 'desperate larvae' in habitats unsuitable for growth and reproduction. The information on the presence of predators can be stored in natural biofilms that are modified by predators. This may happen through bioturbative and/or grazing effects on natural biofilms (see below), or through chemical signals (i.e. kairomones) that are being trapped and stored in biofilms, where bacteria may play a predominant role (Harder et al. 2002). That bacterial communities are affected by predators, has not been reported before. Here, we tested the hypothesis whether the physical bioturbative or exudative effects of a facultative predatory and a detritivorous harpacticoid copepod and/or the conditioning effect of POM (particulate organic matter) derived from cultures of these copepods affect the attractiveness of natural biofilms, as evidenced by larval settlement of the polychaete Hydroides elegans.

\section{MATERIALS AND METHODS}

Harpacticoid copepod cultivation. All harpacticoid copepod individuals used in this study came from stocks reared in the Coastal Marine Laboratory at the Hong Kong University of Science and Technology (HKUST). More than 10 females of Tisbe japonica (Ho, 1982) and of Nitocra spinipes (Boeck, 1865) (both Copepoda: Harpacticoida) were isolated, maintained and prepared for the experiments according to a procedure described by Dahms et al. (2004). These copepods were collected in June 2004 at the Star Ferry Pier in Tsim Tsa Tsui (Hong Kong, Victoria Harbor). In this habitat larvae of the calcareous tube-building polychaete Hydroides elegans settle as well. Adult females were next separated into individual Petri dishes containing $25 \mathrm{ml}$ of sterile-filtered $(0.22 \mu \mathrm{m})$ seawater (FSW) of 34 ppt salinity and kept at $26^{\circ} \mathrm{C}$ with a photocycle of $12 \mathrm{~h}$ light:12 h dark. The rate of seawater renewal was about $50 \% \mathrm{wk}^{-1}$. The copepods were exclusively fed the single-cell chrysophyte Isochrysis galbana. Supplies of unicellular algae were renewed every $2 \mathrm{~d}$, and food was always in excess, except during the experiments when no food was added.

For each experiment, copepods were selected from among the offspring of about 100 females of the F1 generation carrying egg-sacs, in order to assure a heterogeneous genetic assemblage and behavioral variation in the experimental treatments. The experimental dishes were kept under the same conditions as the culture bowls with respect to water quality, temperature, light and algal growth, in order to allow fast adaptation after individual females or developmental instars were transferred (see details in Dahms et al. 2004).

Cultivation of larvae and algae. Adults of the serpulid tubeworm Hydroides elegans (Haswell, 1883) (Polychaeta: Serpulidae) were collected from submerged rafts at the fish-farm at Wong Shek in Hong Kong waters $\left(22^{\circ} 19^{\prime} \mathrm{N}, 114^{\circ} 16^{\prime} \mathrm{W}\right)$ on 23 July 2003. Larval cultures were maintained and larval competency was evaluated according to Pechenik \& Qian (1998). The chrysophyte Isochrysis galbana (Tahitian strain) was grown in monospecific algal cultures of f/2-medium at $34 \mathrm{ppt}$ salinity and at $26^{\circ} \mathrm{C}$ under continuous illumination. Algal cultures in the exponential growth phase were used as food for $H$. elegans larvae and for the copepods.

Enumeration of bacteria in biofilms. Bacteria attached onto Petri dishes $(\mathrm{n}=3$ ) were fixed in $4 \%$ formalin in FSW, rinsed with FSW and stained with the DNA-binding fluorochrome 4,6-diamidino-2phenylindole (DAPI, Fluka Chemie), at $0.5 \mu \mathrm{g} \mathrm{ml} \mathrm{m}^{-1}$ for $15 \mathrm{~min}$. The number of bacteria in 10 randomly selected fields of view were then enumerated using epifluorescence microscopy at a magnification 
of 1250x (ZEISS Axiophot fluorescence microscope, magnification $\left.1250 \times, \lambda_{\mathrm{EX}}=359 \mathrm{~nm}, \lambda_{\mathrm{EM}}=441 \mathrm{~nm}\right)$.

Extraction of bacterial community DNA and PCR. The bacterial community DNA was extracted and isolated according to the method described by Liu et al. (1997). Biofilm samples from Repeats 1 to 3 were scraped off the dishes (area per dish: $19.625 \mathrm{~cm}^{2}$ ) using sterile brushes. Removed biofilms were suspended in $0.8 \mathrm{ml}$ of lysis buffer (1\% Triton X-100, 20 mM TrisHCL at pH 8.2). PCR of $16 \mathrm{~S}$ rRNA genes (rDNA) in the bacterial community DNA was performed in a total volume of $25 \mu \mathrm{l}$, containing $1 \mu \mathrm{l}$ of DNA template, $250 \mu \mathrm{l}$ of each desoxyribonucleotide triphosphate (dATP, dTTP, dCTP, dGTP; Pharmacia Biotechnology), $1 \mathrm{U}$ of buffered AmpliTaq GoldTM DNA polymerase (Applied Biosystems), $1.5 \mathrm{mM} \mathrm{MgCl} 2$ and $1 \mu \mathrm{M}$ of each universal primer (341F: 5'-CCTACGGGAGGCAGCAG-3' and 926R-Fam: 5'-CCGTCAATTCCTTTRAGTTT-3'). The 926R-FAM was labeled at the 5'-end with the phosphoramidite dye 5-hexachlorofluorescein. PCR was performed at $95^{\circ} \mathrm{C}$ for $10 \mathrm{~min}$; then 35 cycles at $95^{\circ} \mathrm{C}$ for $1 \mathrm{~min}, 55^{\circ} \mathrm{C}$ for $1 \mathrm{~min}$ and $72^{\circ} \mathrm{C}$ for $1 \mathrm{~min}$; and a final step at $72^{\circ} \mathrm{C}$ for $5 \mathrm{~min}$. Amplification of DNA was verified by electrophoresis of $5 \mu \mathrm{l}$ of PCR products in $1.5 \%$ agarose in TAE buffer (40 mM Trisacetate, 1 mM EDTA, pH 8.0).

T-RFLP analysis. Fluorescently labeled PCR products were digested with $20 \mathrm{U}$ MspI (Boehringer Mannheim Biochemicals) at $37^{\circ} \mathrm{C}$ for $6 \mathrm{~h}$. Digested amplicons were purified with the Wizard PCR preps DNA purification system (Promega) according to the manufacturer's protocol. Aliquots of purified products $(10 \mu \mathrm{l})$ were mixed with $0.5 \mu \mathrm{l}$ of internal size standard (ET-550, Amersham). This mixture was denatured for 5 min at $95^{\circ} \mathrm{C}$ and immediately chilled on ice before electrophoresis on a MegaBace genetic analyzer (Amersham) operated in genotyping mode. After electrophoresis, the length of the fluorescently labeled terminal-restriction fragments (T-RFs) was determined by comparison with internal standards, using fragment profiler software (Amersham). For each sample, peaks over a threshold of 50 relative fluorescence units were used, and terminal fragments $<35$ and $>500 \mathrm{bp}$ were excluded from the analysis to avoid detection of primers and uncertainties in size determination. The most prominent T-RF peaks $(\mathrm{n}=21)$ were compared with the respective basepair characteristics of bacterial strains in the HKUST bacterial culture collection (Table 1).

Larval bioassay. Adults of the polychaete Hydroides elegans were collected from submerged rafts at the fish-farm in Wong Shek in Hong Kong waters $\left(22^{\circ} 19^{\prime} \mathrm{N}, 114^{\circ} 16^{\prime} \mathrm{W}\right)$. Only competent larvae were included in the larval settlement bioassays. Competence of $H$. elegans larvae was determined according to the method described by Pechenik \& Qian (1998). A larval bioassay was conducted with replications $(n=5)$ in multi-well polystyrene dishes (No. 3047, FALCON)

Table 1. Taxonomic status of bacterial isolates from a $5 \mathrm{~d}$ old natural biofilm representing particular bacterial strains (as deduced from the peak position in the electropherograms when compared to those of bacterial strains in the HKUST culture collection)

\begin{tabular}{|lcll|}
\hline $\begin{array}{l}\text { Peak position } \\
\text { (T-RFL) }\end{array}$ & $\begin{array}{c}\text { Predicted peak } \\
\text { position }\end{array}$ & Species/strain designation & $\begin{array}{l}\text { GenBank } \\
\text { accession no. }\end{array}$ \\
\hline 30 & 30 & Bacillus halmapalus (DSM 8723) & AF235119 \\
31 & 31 & Alteromonas sp. KT0903 & AF280818 \\
128 & 128 & Pseudoalteromonas sp. DC1 & \\
207 & 207 & Slope Strain DIII1C & AF254111 \\
209 & 209 & Brevibacterium casei (NCDO 2048) & DLARG16SB \\
210 & 210 & Slope strain DIII1C & \\
246 & 246 & Deleya marina (ATCC25374) & \\
283 & 283 & Micrococcus kristinae & \\
300 & 300 & Rhodovulum sp. & AJ293802 \\
302 & 302 & Kocuria rhizophila & Axiguobacterium aurantiacum \\
304 & 304 & Vibrio pelagicus & AJ000726 \\
311 & 311 & North Sea bacterium H7 & \\
312 & 312 & Marinobacter aquaelei & \\
313 & 313 & Vibrio spendidus bivar II & \\
314 & 314 & Flavobacterium salegens & X77445 \\
342 & 342 & Planococcus citreus & AJ293474 \\
372 & 372 & Aureibacterium testaceum (DSM 20166) & AB021404 \\
373 & 373 & Stenotrophomonas maltophilia Strain e-a22 & AF068008 \\
423 & 423 & Pseudomonas geniculata Strain ATCC 19374T & \\
424 & Stenotrophomonas altophilia Strain VUN 10, 010 & \\
425 & 424 & &
\end{tabular}


containing 20 larvae of $H$. elegans. Non-biofilmed dishes filled with autoclaved filtered seawater were used as negative controls. Larval attachment assays were run at $24^{\circ} \mathrm{C}$ under continuous illumination for $24 \mathrm{~h}$. After this period of time, swimming, settled and dead larvae (i.e. showing no locomotory or ciliary movements) were counted under a dissecting microscope.

Experimental design. The laboratory experiments were designed to test whether the settlement of competent larvae of Hydroides elegans was affected by the conditioning effects of the facultative predatory copepod Tisbe japonica (cf. Dahms et al. 2004), through either the presence of live copepods on the biofilms or the presence of their remains (attached bacteria, dissolved organic matter [DOM], or particulate organic matter $[\mathrm{POM}])$ in culture. The dishes were rinsed carefully prior to the addition of larvae in the larval settlement bioassays.

Natural biofilms were developed on polystyrene Falcon Petri dishes (FALCON No. 1006). The Petri dishes were arranged in troughs and exposed to running seawater in the wetlab of the Coastal Marine Laboratory for $5 \mathrm{~d}$ at $22^{\circ} \mathrm{C}$. To develop bacterial films we followed the stages described by Lau \& Qian (1997). The $5 \mathrm{~d}$ old biofilms were covered by $4.5 \mathrm{ml}$ of sterile, filtered $(0.22 \mu \mathrm{m})$ seawater and subjected to $6 \mathrm{~h}$ of exposure to POM derived from the settled substrate in the culture bowls of the predatory harpacticoid copepod Tisbe japonica or the detritivorous harpacticoid copepod Nitocra spinipes; other treatments involved the addition of different numbers of live individuals of $T$. japonica $(10,20$, or 30 individuals in a balanced sex ratio) to the Petri dishes covered with $5 \mathrm{~d}$ old biofilms (see below for biofilm development) prior to the larval bioassay experiments. The POM (detritus, consisting of feces, molts, dead corpses and associated microorganisms) was taken from the culture bowls. The particular treatments used in the experiments are as follows: untreated control (Con), biofilmed dishes conditioned with POM of T. japonica (CBFTij), dishes conditioned with POM from the culture bowls of $N$. spinipes (CBFNsp), natural biofilms exposed to 10 individuals of T. japonica (Tij10), natural biofilms exposed to 20 individuals of $T$. japonica (Tij20) and natural biofilms exposed to 30 individuals of $T$. japonica (Tij30). After $6 \mathrm{~h}$ of conditioning, the dishes were emptied and dipwashed 3 times in $500 \mathrm{ml}$ of filtered seawater (FSW) in order to remove loosely attached cells, POM and copepods. In the treatments with live copepods, the dishes were checked individually for copepods still attached to the biofilms, which were then removed by pipetting. Twenty larvae of Hydroides elegans were transferred to each experimental dish filled with $5 \mathrm{ml}$ of FSW and kept there for $24 \mathrm{~h}$.
Statistical analysis. The normality of the bacterial density and of the settlement data was substantiated by Shapiro-Wilk's $W$-test (Shapiro \& Wilk 1965). The percentage data were arcsine-transformed. To improve the transformation, those replicates with no larval settlement were given the value of $1 / 4 n$ (n: number of larvae in a single replicate) (Zar 1999). Since the data did not meet the ANOVA assumptions, all treatments were analyzed non-parametrically by transformation of the values to ranks, followed by a 1-way ANOVA and an LSD (least significant difference) post hoc test $(\alpha=0.05)$. The data presented in the figures are not transformed. The software package Statistica (StatSoft) was used for the computational analyses.

The T-RFLP patterns were analyzed by calculating the total number of T-RFs observed in all samples and the presence or absence of these T-RFs in individual samples. Bray-Curtis similarity matrices were used for hierarchical clustering. The result obtained with an unweighted group average method was displayed as a dendrogram using the statistical software program PRIMER (Clarke \& Warwick 1994). The results of 5 replicate assays and 3 experimental repeats for each treatment were pooled to carry out Spearman's rank order correlation analysis between larval settlement and bacterial abundance on the biofilmed dishes.

\section{RESULTS}

\section{Changes of bacterial abundance and community profile}

Density of bacteria after $6 \mathrm{~h}$ of incubation

Bacterial densities were significantly different between the control and 4 of 5 treatments -3 of these being significantly lower and 1 significantly higher than the control (Fig. 1, 1-way ANOVA: $F_{5,24}=3.325$, $\mathrm{p}<0.004)$. The highest bacterial density was recorded on the dishes conditioned with the POM of Tisbe japonica, the second highest bacterial density was on the dishes conditioned with the POM from Nitocra spinipes and the control dishes. The lowest bacterial densities were observed on the dishes exposed to live T. japonica; here, a clear inverse relationship was indicated between copepod and bacterial densities.

\section{Bacterial community profiles}

Under the combination of PCR primers and the restriction enzyme used in this study, the number of discernible T-RFs of bacterial DNA obtained from the experimental and the control treatments varied sub- 


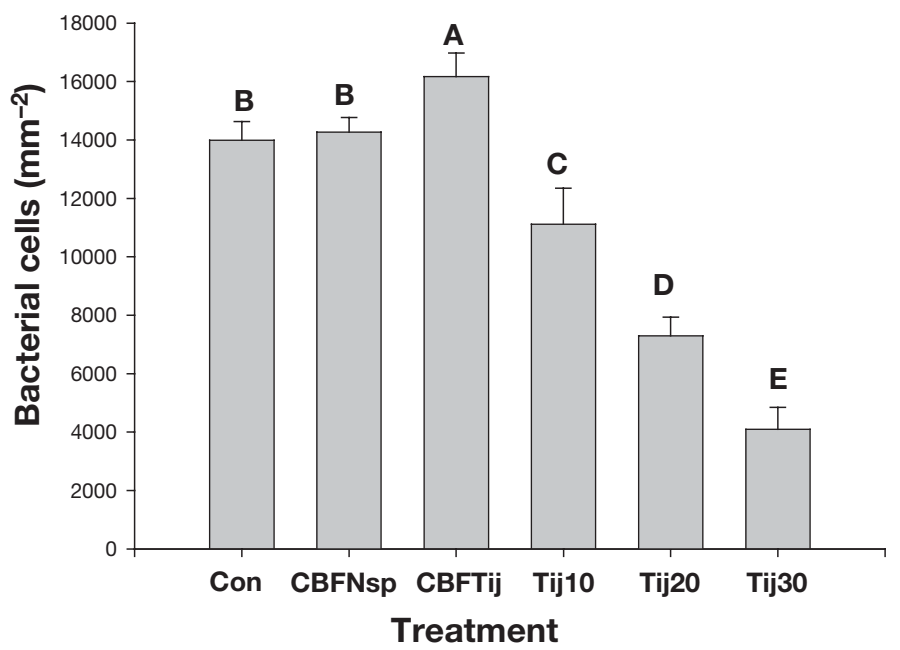

Fig. 1. Bacterial densities. Mean (+SD of 3 repeats) microbial (bacterial) abundance on a $5 \mathrm{~d}$ old biofilm (BF) on polystyrene FALCON Petri dishes after incubation with particulate organic matter (POM) from culture bowls, or exposed to different densities of the predatory Tisbe japonica. Data presented for 3 experimental repeats (Repeats 1 to 3 ) and 10 randomly selected fields of view per repeat (DAPI-stained bacteria) using epifluorescence microscopy (Con: natural biofilm covered with sterile, filtered [0.22 $\mu \mathrm{m}]$ seawater; CBFNsp and CBFTij: natural biofilms conditioned with POM of Nitocra spinipes and $T$. japonica, respectively; Tij10: natural biofilms exposed to 10 individuals of $T$. japonica; Tij20: natural biofilms exposed to 20 individuals of $T$. japonica; Tij30: natural biofilms exposed to 30 individuals of $T$. japonica). Means significantly different in the LSD test ( $p<0.05,1$-way ANOVA) are indicated by different letters above the bars

stantially (1-way ANOVA: $\left.F_{5,24}=6.345, \mathrm{p}<0.05\right)$ (Fig. 2). The T-RFLP technique also provided preliminary information about relative abundances and identities of ribotypes in the HKUST bacterial culture collection. This was done by comparing the respective lengths of the T-RFs obtained during the present study with those from the bacterial culture collection of the HKUST.

T-RF peak positions most probably correspond to the bacterial strains described in Table 1, which are included in the HKUST's bacterial culture collection. Differences in the bacterial community profiles are shown in the T-RF length patterns of the PCR-amplified bacterial community DNA obtained from the experimental dishes (Fig. 2). The community profiles were only slightly different on the control and treatment surfaces. The bacterial communities developed on treated dishes, in comparison with the untreated dishes, were characterized by either the absence of certain T-RFs (e.g. $250 \mathrm{bp}$ ) or the presence of certain T-RFs (e.g. 128, 232, $313 \mathrm{bp}$ ).

Bray-Curtis similarity matrices were calculated by using the presence (indicated by 1) and absence (indicated by 0 ) of a given T-RF in a pattern as the 4th-root-transformed presence/absence data of the T-RFs. The bacterial communities were divided into several groups (Fig. 3-the sample of CBFNspII was lost during processing). Cluster analysis identified 2 main clusters with a similarity of about $50 \%, 1$ of which includes all repeats belonging to the control group and to the POM-conditioned biofilms of Tisbe japonica, while the other includes all repeats of the POMconditioned biofilms of Nitocra spinipes and of the treatment with 20 live individuals of T. japonica (Fig. 3). At the same time, bacterial communities that developed on the control surfaces were different from those of the treatments, as indicated by a separate cluster. The different copepod treatments did not change bacterial communities, given the similarities between different treatments (i.e. all replicates of CBFTij and Tij10III treatments; all replicates of Tij20 and Tij30III).

An MDS (multidimensional scaling) ordination of Bray-Curtis similarities confirmed the possible bacterial community effect of the different copepod treatments. The control community was different from that of the treatments (Fig. 4). All replicates of CBFTij and replicates of CBFNsp were grouped in separate clusters, while other treatments were interspersed.

\section{Relationship between larval settlement and biofilm-related attributes}

The statistical patterns of larval settlement in the laboratory experiments were consistent among the 3 experimental repeats (Fig. 5). With the exception of Repeat 2, the larval settlement in the CBFNsp dishes and biofilms was significantly different (1-way ANOVA, $F_{5,24}=24.730, \mathrm{p}<0.05$ ) from the larval settlement in the control dishes. Larval settlement in the presence of live copepods, or after conditioning the natural biofilm of the experimental dishes with POM from the respective culture bowls of Tisbe japonica or Nitocra spinipes was significantly lower than the larval settlement in the control dishes (1-way ANOVA, LSD, $\mathrm{p}<0.001)$. After the conditioning of biofilms with live copepods, the larval settlement density decreased in all treatments. No larva of Hydroides elegans died in any of the treatments.

The highest larval settlement density was recorded in the treatment with POM of the detritivorous Nitocra spinipes, but settlement was less dense in the treatment with the POM of the predatory Tisbe japonica (1-way ANOVA, LSD, p < 0.05) in only 1 of the 3 repeats. Treatments with $>10$ individuals were consistently different from the control and showed decreasing percentages of settlement with increasing copepod numbers. Significant differences in larval settlement were observed in the treatments with different densities of living $T$. japonica - with the lowest settlement at the highest densities of $T$. japonica in all 3 repeats. 

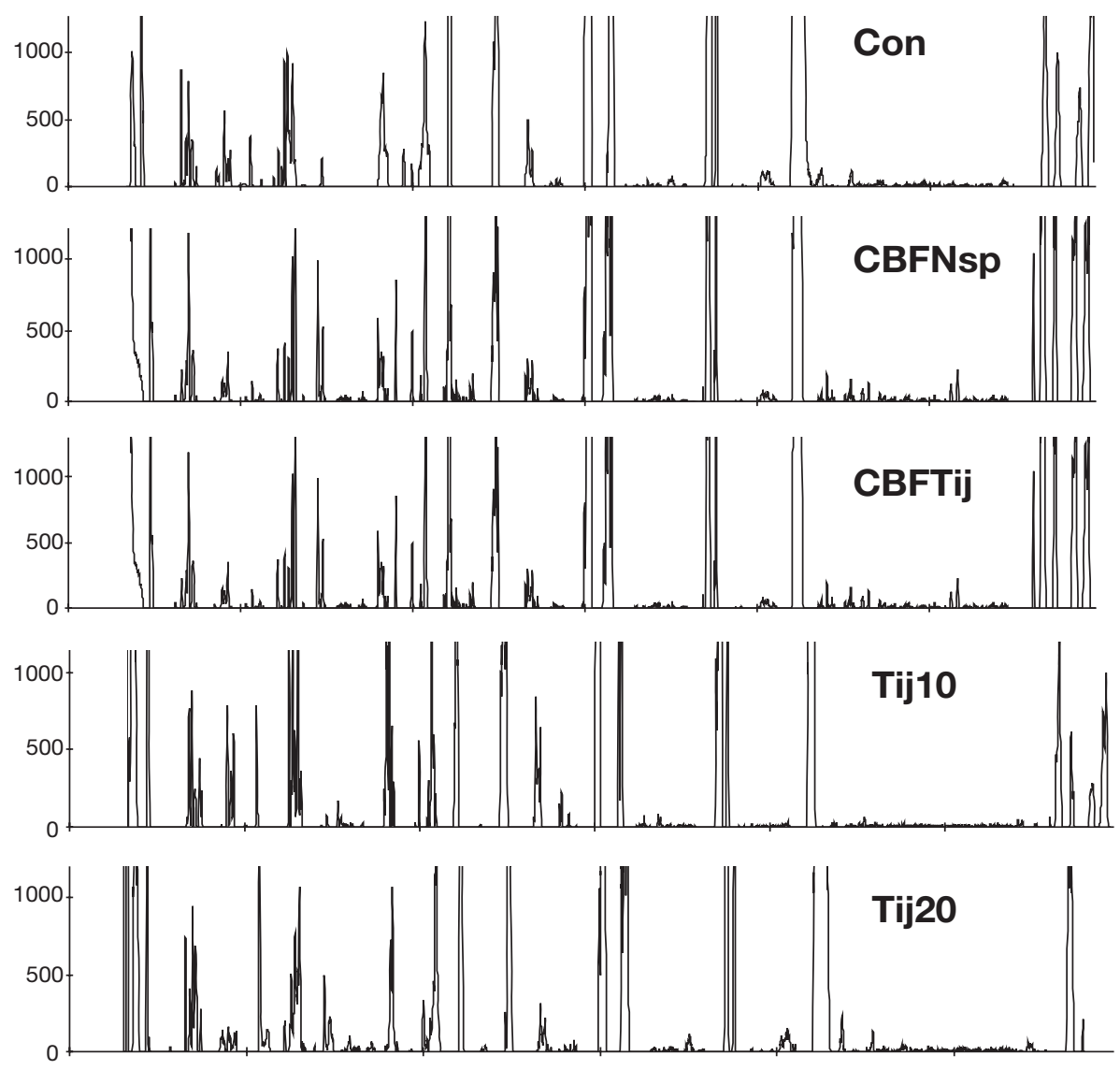

Fig. 2. Representative electropherograms of 5 '-end terminal restriction fragments (T-RFs) ( 1 of the 3 repeats selected randomly is shown) of control (Con: natural biofilm) and experimental Petri dishes conditioned with POM of Nitocra spinipes (CBFNsp) or Tisbe japonica (CBFTij) or with live individuals of $T$. japonica abbreviations as in Fig. 1

Overall, significantly lower densities of settlement were recorded in the treatments with the highest abundances of copepods. The lowest settlement density of Hydroides elegans was found at the highest copepod densities of 30 individuals.

It has to be considered, however, that settling differences of recruitment in the field showing a range from 5 to $10 \%$ of a cohort would be invisible, given that new cohorts of larvae will pass across a surface at frequent intervals. If only $5 \%$ of a single cohort avoided a surface because of the presence of copepods-or the 'memory of copepods' - then one would never detect this on a surface exposed to constantly shifting or mixed cohorts of larvae.

A Spearman-rank correlation between bacterial densities and larval settlement exhibited a clear correlation (Fig. 6): the higher the bacterial densities, the higher the percentage of larval settlement. However, the highest bacterial density was discernible in the dishes conditioned with POM from cultures of the predatory Tisbe japonica (Fig. 1), although we found a lower larval settlement in these dishes compared with the POM-conditioned treatments of the detritivorous Nitocra spinipes.

\section{DISCUSSION}

In our study, in 2 of 3 replicates, the highest settlement of Hydroides elegans larvae occurred on biofilms conditioned with POM from the detritivorous Nitocra spinipes (Fig. 5). This is reasonably explained by the more attractive or less repellent effect of these biofilms compared to those conditioned with POM from the predatory Tisbe japonica. The bacterial communities conditioned with POM from T. japonica (CBFTij) are grouped in a distinct cluster (Fig. 3), demonstrating the effect of this treatment on bacterial communities. This, in turn, might have caused differential larval settlement (Fig. 5). Live T. japonica, however, had the most 


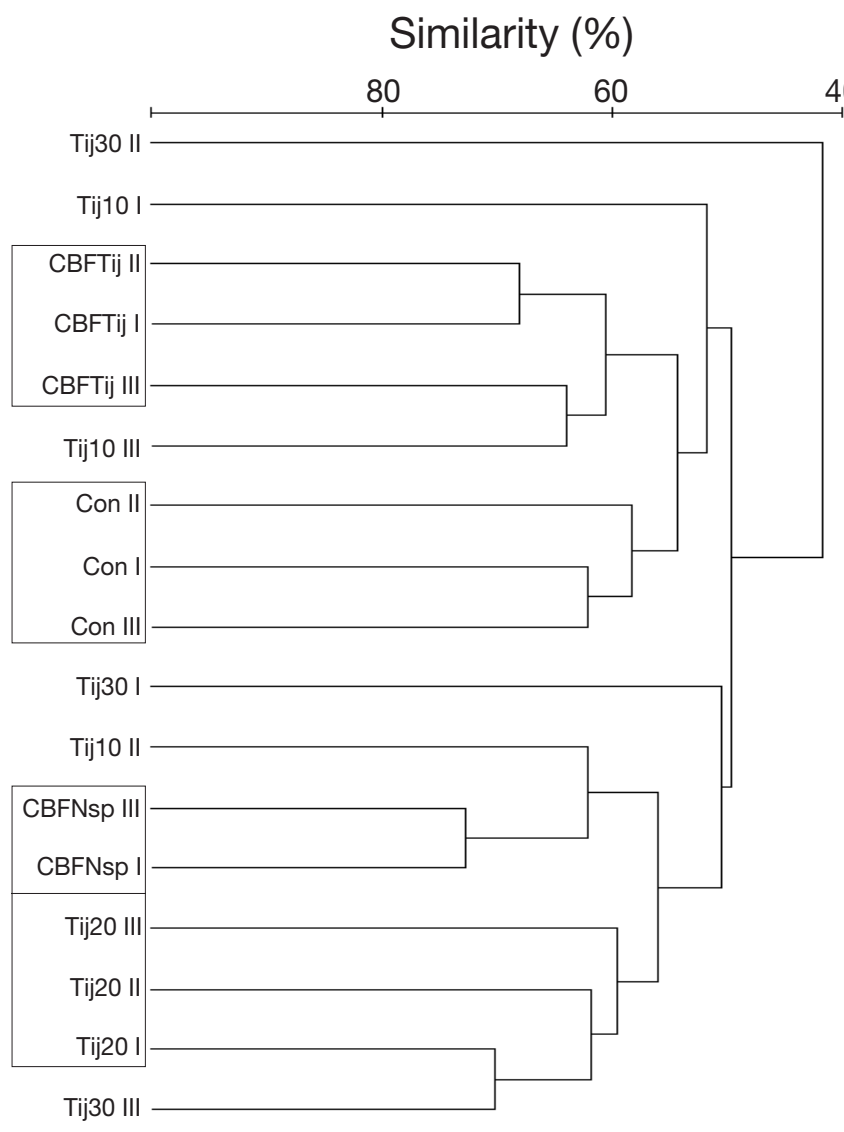

Fig. 3. Dendrogram compiled from Bray-Curtis similarity matrices for the T-RF profiles of untreated control (Con: natural biofilm) and treated biofilms (abbreviations as in Fig. 1; CBFNspII data were discarded). The dendrogram was constructed by using similarity matrices of T-RFs of the bacterial community DNA samples determined by the Bray-Curtis similarity coefficient

striking inhibitive effects on larval settlement, which correlated with a reduction in bacterial densities. This can be explained by the finding that $H$. elegans' larvae prefer high bacterial densities for settlement (see below and Lau et al. 2002). An alternative explanation is that metabolic substances with pheromonal functions (i.e. kairomones) could have been exudated by the copepods. It is reasonable to assume that a higher number of copepods will secrete more kairomones and may have a greater repulsive effect. However, such compounds must be stored in the biofilm matrix, considering that the treatment dishes were dip-washed after a $6 \mathrm{~h}$ incubation period and no copepod was present thereafter. Hence, environmental information could have been stored only in the composition and/or chemistry of the altered biofilms. Due to their distinctive binding properties, exopolymers (EPS) may retain metabolites that store historical and recent environmental information (Harder et al. 2002, see below).

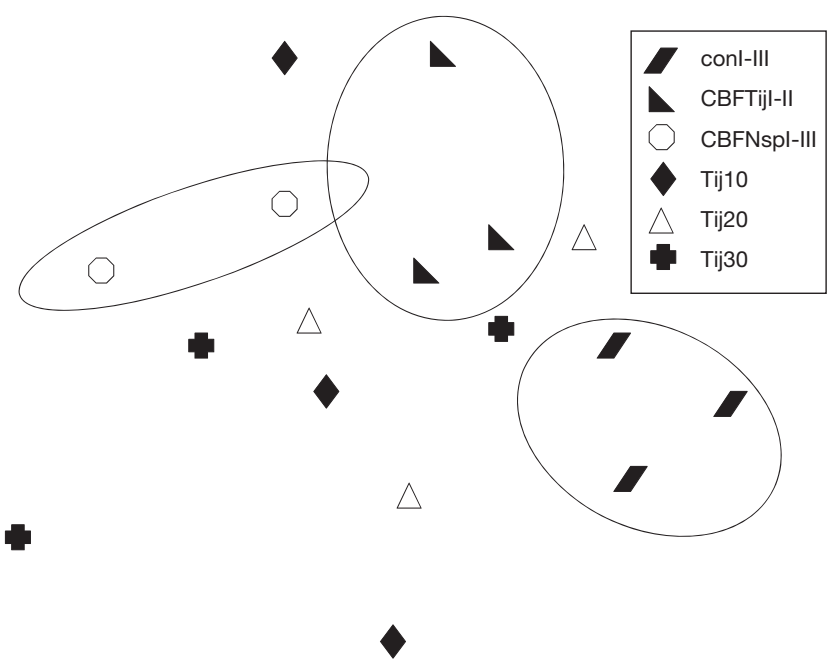

Fig. 4. Two-dimensional MDS (multidimensional scaling) ordination of T-RFs of bacterial communities. DNA samples obtained from 3 replicate surfaces after $6 \mathrm{~h}$ of development of the blank control (Con) and treated biofilms (abbreviations as in Fig. 1; CBFNspII data were discarded)

\section{Larval settlement of the polychaete Hydroides elegans}

The larval settlement of the serpulid polychaete Hydroides elegans has been extensively studied. The larval settlement of this species has been shown to be influenced by flow hydrodynamics (Qian et al. 2000), or to be induced by natural biofilms (Carpizo-Ituarte \& Hadfield 1998), algal metabolites (Lau \& Qian 1997) and the leachates of conspecifics (cf. Henschel \& Cook 1990) or hosts (Bryan et al. 1998). Allelochemicals (Harder et al. 2002) or metabolites from microbial biofilms (Lau et al. 2002) can either facilitate or inhibit larval settlement of $H$. elegans (Bryan et al. 1998). Disturbance effects of predators on the larval settlement of $H$. elegans were studied by Dahms et al. (2004).

\section{Larval disturbance due to behavioral irritation by predators}

The sublethal and irritational effects of predators on their larval prey have largely been ignored in the study of marine invertebrate larval settlement. Larvae of some species may postpone their metamorphosis if they sense the presence of dominant competitors on substrates they examine (Young \& Chia 1981). Johnson (1989) found that settling barnacle larvae avoid substrata that have previously been occupied by a mobile predator. Dahms et al. (2004) showed that larvae of Hydroides elegans did not settle when they were exposed to increasing densities of disturbers, both in 

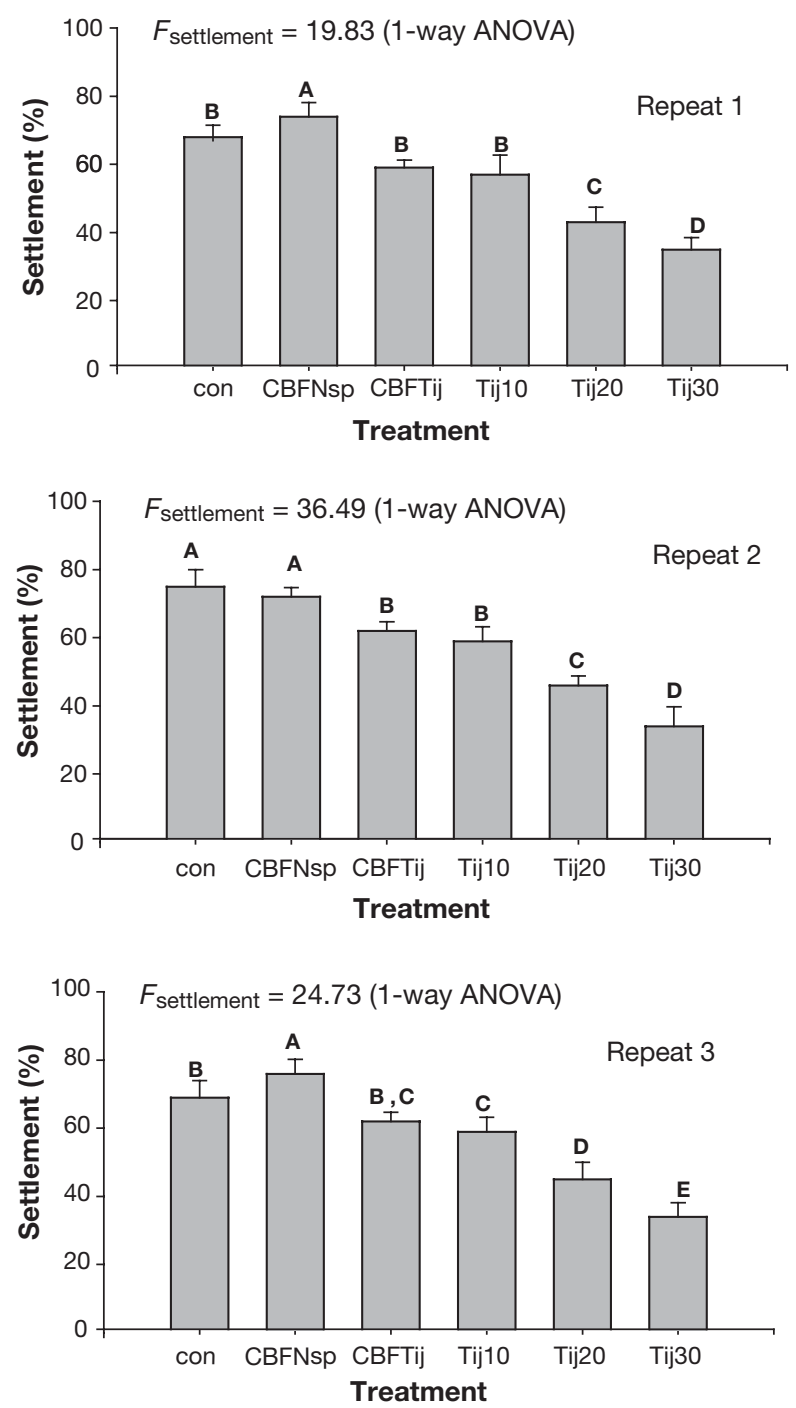

Fig. 5. Hydroides elegans. Settlement response of competent larvae. Data are means (+SD) of 5 replicate dishes. Different letters above the bars indicate data that are significantly different according to an LSD (least significant differences) test $(p<0.05,1$-way ANOVA). Data presented for 3 experimental repeats (Repeats 1 to 3 ) of control (con) and treated biofilms (abbreviations as in Fig. 1)

the laboratory and the field, irrespective of their physical elimination through predation.

\section{Disturbance of the larval settlement process by meiofauna}

Experimental investigations of biotic disturbances on larvae have been limited to the short time-window of immigration of dispersal stages (Gaines \& Roughgarden 1985). When macrofaunal larvae or juveniles recruit to the benthos, they are in the size category of meiofauna. Due to growth, they belong to this faunal fraction only temporarily (and therefore are called temporary meiofauna, contrary to permanent meiofauna; see Vanaverbeke et al. 1997).

The permanent meiofauna includes predators that prey on settling macrofauna. Watzin (1983) showed that several groups of macroinvertebrate larvae are the prey of permanently meiofaunal turbellarians, nematodes and copepods. Harpacticoid copepods have been shown to be facultative predators of polychaete larvae in previous studies (Watzin 1983, Dahms et al. 2004). In addition to macrofauna, they are significant bioturbators (Hicks \& Coull 1983). High levels of bioturbation may make it difficult for juvenile macrofauna to remain in sediments or may otherwise mediate the immigration of new settlers. Some meiofaunal taxa may be particularly attracted to disturbed or even defaunated substrates (Thistle 1981).

Apart from causing bioturbation, the meiofauna also affects microbial communities through grazing and fertilization (cf. Carman 1994). Since marine invertebrate larvae are known to distinguish between biofilms on the basis of properties such as microbial density, composition and age (Wieczorek \& Todd 1998), the merely physical alteration of biofilms by meiofaunal components may subsequently change the behavior of larvae.

\section{Natural biofilms, bacterial densities and community profiles}

Densities, community structures and biochemical properties of the microorganisms in natural biofilms may vary temporally and spatially. In previous studies, bacterial abundance was used as the main characteristic of biofilm quality for larval settlement modulation. Qian et al. (2003), however, did not substantiate any significant correlation between larval settlement of the cirriped Balanus amphitrite and bacterial densities.

Larvae of Hydroides elegans have been observed to prefer older biofilms, which commonly have higher bacterial densities (Jin \& Qian 2004). The present study confirms those findings. Larval settlement of $H$. elegans was positively correlated with bacterial densities (Fig. 6). The only exception to this commonality is constituted by the observation that biofilms conditioned with POM from Nitocra spinipes showed the highest settlement (Fig. 5), while showing a lower bacterial density than the biofilms conditioned with Tisbe japonica POM (Fig. 1). The latter caused less larval settlement in all 3 repeats than had the $N$. spinipes POMconditioned biofilm (Fig. 5). A significant increase in bacterial abundances on the Tisbe japonica POM-conditioned biofilm during the present study could also be 


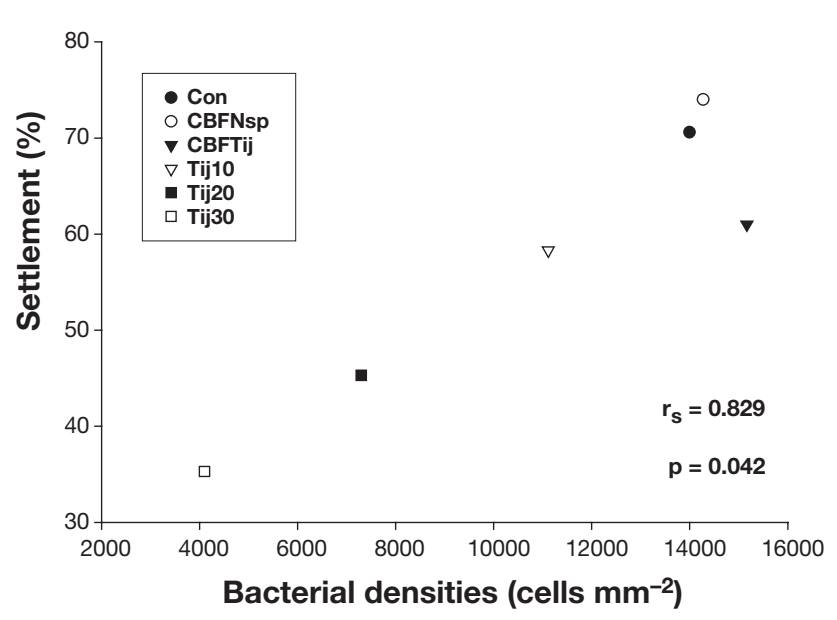

Fig. 6. Hydroides elegans. Relationship between the bacterial densities and percentages of larval settlement for the different treatments. Mean bacterial abundances for 6 treatments (each represented by 3 experimental repeats numbering 5 replicates each) were plotted along the $x$-axis. Mean values of larval settlement are shown along the $y$-axis $\left(\mathrm{r}_{\mathrm{s}}\right.$ : Spearman rank correlation coefficient). Data presented for control (Con) and treated biofilms (abbreviations as in Fig. 1)

due to a higher load of bacteria from its POM remains that adhered to the $5 \mathrm{~d}$ old biofilm. Alternatively, this POM with an existing biofilm may have provided better growth conditions than the POM derived from cultures of $N$. spinipes, which showed no significant differences in bacterial densities compared to the control. A decrease of bacterial abundance with increasing densities of $T$. japonica (the treatments Tij10, 20, 30 of the present study) can be explained by the grazing impact of the copepods, the physical disturbance caused by the feeding activity of copepods, and/or their swimming/crawling locomotion in the biofilmed dishes. It is reasonable to assume that higher numbers of copepods will have a more profound effect on the biofilms.

An understanding of the correlation between bacterial density, the diversity in natural biofilms and larval settlement provides a way to understand the significance of biofilms as mediators of larval settlement. Thus, ignoring the spatial and temporal changes in the composition of microbial biofilms in earlier studies may have led to misinterpretations of larval settlement processes.

Meanwhile, molecular tools provide a practical means to analyze bacterial community profiles and the diversity of natural biofilms by using the DNA extracted from environmental samples (Davey \& Toole 2000). Bacterial communities from various habitats have lately been studied through culture-independent molecular methods (Qian et al. 2003). Coupling molecular tools (Dunbar et al. 2001) with larval settlement bioassays allows us to evaluate the role of nonculturable bacteria in regulating larval settlement under in situ conditions (Qian et al. 2003). Among a variety of molecular tools, we utilized the T-RFLP technique because of its straightforward implementation using an automated genetic analyzer (Liu et al. 1997). This method provides sufficient information for revealing diversity differences of bacterial communities from environmental samples (Blackwood et al. 2003). Meanwhile, the T-RFLP method has been successfully applied in the characterization of bacterial communities from enrichment cultures over time, from soil samples and from marine samples (Moeseneder et al. 2001).

However, T-RFLP data can only be regarded as 'semi-quantitative', because of the fact that 1 signal of the electropherogram may represent several bacterial species sharing the same cutting site for the chosen restriction enzyme (Liu et al. 1997). Furthermore, the intensity of individual peaks displayed in the electropherograms does not necessarily reflect the relative abundance of each bacterial taxon in the sample. This is due to possible differential amplification of DNA templates during PCR. For these reasons, peak intensity data cannot be used quantitatively in multivariate analyses. Despite these limitations, the T-RFLP approach is sensitive enough to show bacterial community differences (Blackwood et al. 2003). Since the T-RFLP analysis does not allow genetic identification of particular bacteria in samples, investigators who are interested in this must use other techniques. The most suitable method in describing microbial diversity is surely the analysis of rRNA sequences and the application of fluorescence in situ hybridization. Alternatively, the T-RFLP technique or denaturing gradient gel electrophoresis (DGGE) will allow the creation of clone libraries.

Cross referencing the T-RF data with existing ribosomal sequence databases does provide some information on the possible identity of ribotypes found in the community profiles. This is facilitated by the TAPT-RFLP Java Applet program from the RPD II website. However, one must keep in mind that medically and industrially important cultivable bacteria dominate the RPD II database and that marine bacteria may be underrepresented. For this reason, we used information from the HKUST bacteria database in the present study (Table 1).

\section{Bacterial compounds and larval settlement}

It appears that changes in the bacterial community profiles of the biofilms can affect their attractiveness to the larvae of Hydroides elegans (Lau \& Qian 2001). It is reasonable to expect that complex microbial communi- 
ties show differential bioactivity in terms of chemical compounds affecting other biota. Larval settlement is known to be mediated by 2 major functional types of bacterially derived chemicals: waterborne substances (Fitt et al. 1990) and substances associated with bacterial cell surfaces (Szewzyk et al. 1991). Lau \& Qian (2001) observed that $H$. elegans larvae settled only when exposed to biofilms with live bacteria; the seawater conditioned by the bacteria in suspension was not inductive to larval settlement. These results suggest that the inductive effect of these bacteria on larval settlement is associated with their cell surfaces rather than with their waterborne products. Similar results were obtained by other investigators (see Unabia \& Hadfield 1999).

An example of a bacteria-derived larval-settlement inducer is provided by the exopolysaccharides of the bacterium Halomonas (Deleya) marina that stimulate larval settlement of the polychaete Janua brasiliensis through surface recognition of a galactose-galactose subunit within the polymer (Kirchman et al. 1982). Larval settlement of $J$. brasiliensis was blocked by coating the biofilm with lectins, suggesting that the cue is surface bound and not water soluble. The relevant cues have yet to be characterized and chemically identified. Also, responses of invading biota to monospecific biofilms in the laboratory may not reflect responses to complex microbial communities in the field.

However, in barnacle cyprid settlement, bacteria play a controversial role as far as their inhibitory or facilitative effects are concerned. Wieczorek \& Todd (1998) and later Qian et al. (2003) showed that bacteria may confer attractive properties conductive to the settlement of Balanus amphitrite. Culturable bacteria adapt well to laboratory conditions (Olson et al. 2000), but may actually be functionally inactive minorities in the natural environment (Amann et al. 1995). Such 'laboratory opportunists' have often been used in previous attachment studies. Bacillus spp., Vibrio spp., Alteromonas spp. and Pseudoalteromonas spp. (see Table 1) might belong to this fraction of naturally inactive or subdominant bacterial strains. They are easily grown under laboratory conditions and, therefore, are predominantly used in screening assays. In addition, besides diverse bacterial assemblages, natural biofilms commonly contain other microorganisms that may affect settlement processes. For example, fungi appear to be a common component of marine biofilms (Henschel \& Cook 1990), and biofilms dominated by diatoms are commonly used in abalone aquaculture to induce settlement of their larvae (Morse et al. 1990).

The association of bacterial metabolites with a biofilm surface will be facilitated by the high binding affinities of exopolymers (EPS) surrounding bacterial cells. Exopolymers are surface-active molecules and consist of heteropolysaccharides, proteins and glycoproteins (Decho 1990). Due to their distinctive binding properties, exopolymers may retain bacterial metabolites on their cell surfaces and, additionally, may bind external compounds such as kairomones. Exopolymers can be regarded not only as absorptive matrices, but also as diffusion barriers for metabolites (Decho 1990). It has been suggested that both historical and recent information about a biofilm is stored in the biofilm matrix (Anderson 1995). Environmental information, such as the odors of predators (e.g. kairomones) can be trapped in the mucoid exopolymers secreted by most prokaryotes, as well as by diatoms (cf. Decho 1990). In this context, Clare \& Matsumura (2000) discussed the importance of pheromone perception mediated by biofilms involved in the settlement of barnacles. Meanwhile, bacterial exopolymers and/or their associated compounds have been assigned the role of indicators of substratum suitability for the larvae of Hydroides elegans (Harder et al. 2002, Lau et al. 2002).

Exopolysaccharides of the bacterial glycocalyx were shown to be responsible for the induction of larval settlement of the polychaete Janua brasiliensis (Kirchman et al. 1982), the barnacle Balanus amphitrite and the tunicate Ciona intestinalis (Szewzyk et al. 1991). The settlement-inductive substances remained active after dissociation from bacterial cells and the death of the bacteria. Lau \& Qian (2001) found that larvae did not settle on bacterial films treated with formaldehyde; they settled only in reduced numbers in the presence of streptomycin. Qian et al. (2003) reported that there was no positive correlation between larval settlement of the barnacle $B$. amphitrite and the density of bacteria, but they did not quantify bacterial exopolymers (EPS).

\section{Larval perception of disturbers/predators using microbial communities as a source of information}

The larval settlement process can be affected by the perception of the presence of predators with the possible effect of delaying attachment. A direct way to perceive this kind of interspecific chemical environmental information may be through odors (e.g. kairomones; see above and Johnson 1989). Kairomones trapped in the EPS are hypothesized to modulate biofilm bioactivity in the present study.

An indirect way to perceive a predator could be through effects of a predator on other biota, such as the microbial constituents of biofilms. It has been shown repeatedly (Harder et al. 2002, Qian et al. 2003) that the exploration of biofilms allows larvae to assess the suitability of a given habitat for post-settlement survival. The microbial components of biofilms, especially 
bacteria, are sensitive to changes in environmental parameters; hence, the composition of bacterial communities in biofilms and their physiological status can reflect local environmental conditions of a substratum (Wieczorek et al. 1996). Vagile macrobiota are known to alter the consistency and composition of biofilms by mechanical effects (bioturbation), such as locomotion and physically altering biofilms through foraging (cf. Anderson 1995). Observations revealed that this bioturbative effect also holds for the harpacticoid species used in the present study. Apart from causing bioturbation, harpacticoids have been shown to alter bacterial densities by selective grazing and fertilization processes (Carman 1994).

Although our laboratory experiments provide a controlled environment to assess the roles of biofilms on larval settlement, we must be cautious in extrapolating the laboratory results to field conditions where larval settlement can be influenced by other extrinsic and intrinsic factors. Undoubtedly, a variety of physical and biological factors may contribute to large fluctuations in settlement (e.g. mortality, competition, sedimentation, availability of food resources; see Pawlik 1992). As for biological parameters, besides predators, the presence of conspecifics, competitors and internal larval conditions have also been shown to affect larval settlement (Pechenik 1990). In further attempts, experimental substrata should be exposed in the field and should be monitored for subsequent recruitment of marine invertebrate larvae, such as polychaete larvae.

Acknowledgements. We acknowledge the assistance of staff members in the Coastal Marine Laboratory of the Hong Kong University of Science and Technology (HKUST), particularly Ms. Man-Yi Tsoi who helped in various ways during this study. This investigation was supported as part of an AoE project of the 'Centre for Marine Environmental Research and Innovative Technology' (AOE/P-04/04-2) to P.-Y.Q.

\section{LITERATURE CITED}

Amann RI, Ludwig W, Schleifer KH (1995) Phylogenetic identification and in situ detection of individual microbial cells without cultivation. Microbiol Rev 59:143-169

Anderson MJ (1995) Variations in biofilms colonizing artificial surfaces: seasonal effects and effects of grazers. J Mar Biol Assoc UK 75:705-714

Blackwood CB, Marsh T, Kim SH, Paul EA (2003) Terminal restriction fragment length polymorphism data analysis for quantitative comparison of microbial communities. Appl Environ Microbiol 69:926-932

Bryan JP, Kreider JL, Qian PY (1998) Settlement of the serpulid polychaete Hydroides elegans (Haswell) on the arborescent bryozoan Bugula neritina (L.): evidence of a chemically mediated relationship. J Exp Mar Biol Ecol 220:171-190

Carman KR (1994) Stimulation of marine free-living and epibiotic bacterial activity by copepod excretions. FEMS Microbiol Ecol 14:255-262
Carpizo-Ituarte E, Hadfield MG (1998) Stimulation of metamorphosis in the polychaete Hydroides elegans Haswell (Serpulidae). Biol Bull (Woods Hole) 194:14-24

Clare AS, Matsumura K (2000) Nature and perception of barnacle settlement pheromones. Biofouling 15 (1/3):57-71

Clarke KR, Warwick RM (1994) Changes in marine communities. Bourne Press, Plymouth

Dahms HU, Harder T, Qian PY (2004) Effect of meiofauna on macrofauna recruitment: settlement inhibition of the polychaete Hydroides elegans by the harpacticoid copepod Tisbe japonica. J Exp Mar Biol Ecol 311:47-61

Davey ME, O'Toole GA (2000) Microbial biofilms: from ecology to molecular genetics. Microbiol Mol Biol Rev 64: 847-867

Decho AW (1990) Microbial exopolymer secretions in ocean environments: their role(s) in food webs and marine processes. Oceanogr Mar Biol Annu Rev 28:73-153

Delany J, Myers AA, McGrath D, O'Riordan RM, Power AM (2003) Role of post-settlement mortality and 'supply-side' ecology in settling patterns of intertidal distribution in the chthamalid barnacles Chthamalus montagui and C. stellatus. Mar Ecol Prog Ser 249:207-214

Dunbar J, Ticknor LO, Kuske CR (2001) Phylogenetic specificity and new method for analysis of terminal restriction fragment profiles of 16S rRNA genes from bacterial communities. Appl Environ Microbiol 67:190-197

Fitt WK, Loon SL, Walch M, Weiner RM, Colwell RM, Bonar DB (1990) Settlement behavior and metamorphosis of oyster larvae (Crassostrea gigas) in response to bacterial supernatants. Mar Biol 106:389-394

Gaines S, Roughgarden J (1985) Larval settlement rate: a leading determinant of structure in an ecological community of the marine intertidal zone. Proc Natl Acad Sci USA 82:3707-3711

Harder T, Lau SCK, Dahms HU, Qian PY (2002) Isolation of bacterial metabolites as natural inducers for larval settlement in the marine polychaete Hydroides elegans (Haswell). J Chem Ecol 28(10):2029-2043

Henschel JR, Cook PA (1990) The development of a marine fouling community in relation to the primary film of microorganisms. Biofouling 2:1-11

Hicks GRF, Coull BC (1983) The ecology of marine meiobenthic harpacticoid copepods. Oceanogr Mar Biol Annu Rev 21:373-381

Jin T, Qian PY (2004) Effect of amino acids on larval metamorphosis of the polychaete Hydroides elegans. Mar Ecol Prog Ser 267:209-218

Johnson LE (1989) Settling barnacle larvae avoid substrata previously occupied by a mobile predator. J Exp Mar Biol Ecol 128:87-103

Kirchman D, Graham S, Reish D, Mitchell R (1982) Bacteria induce settlement and metamorphosis of Janua (Dexiospira) brasiliensis Grube (Polychaeta: Spirorbidae). J Exp Mar Biol Ecol 56:153-163

Lau SCK, Qian PY (1997) Phlorotannins and related compounds as larval settlement inhibitors of the tube-building polychaete Hydroides elegans. Mar Ecol Prog Ser 159: 269-277

Lau SCK, Qian PY (2001) Larval settlement in the serpulid polychaete Hydroides elegans in response to bacterial films: an investigation of the nature of putative larval settlement cue. Mar Biol 138:321-328

Lau SCK, Mak KKW, Chen F, Qian PY (2002) Bioactivity of bacterial strains isolated from marine biofilms in Hong Kong waters for the induction of larval settlement in the marine polychaete Hydroides elegans. Mar Ecol Prog Ser 226:301-310 
Liu WT, Marsh TL, Cheng H, Forney LJ (1997) Characterization of microbial diversity by determining terminal restriction fragment length polymorphisms of genes encoding 16S rRNA. Appl Environ Microbiol 63:4516-4522

Marshall DJ, Keough MJ (2003) Variation in the dispersal potential of non-feeding invertebrate larvae: the desperate larva hypothesis and larval size. Mar Ecol Prog Ser 255:145-153

McClintock JB, Baker BJ (eds) (2001) Marine chemical ecology. CRC Press, Boca Raton, FL

Moeseneder MM, Winter C, Arrieta JM, Herndl GJ (2001) Terminal restriction fragment length polymorphism (T-RFLP) screening of a marine archaeal clone library to determine the different phylotypes. J Microbiol Methods 44:159-172

Morgan SG (1995) Life and death in the plankton: larval mortality and adaptation. Ecol Mar Invertebr Larvae 464: $279-321$

Morse DE, Hooker N, Duncan H, Jensen L (1990) Aminobutyric acid, a neurotransmitter, induces planktonic abalone larvae to settle and begin metamorphosis. Science 204: 407-410

Nakaoka M (2000) Nonlethal effects of predators on prey populations: predator-mediated change in bivalve growth. Ecology 81:1031-1045

Olson JB, Cord CC, McCarthy PJ (2000) Improved recoverability of microbial colonies from marine sponge samples. Microb Ecol 40:139-147

Pawlik JR (1992) Chemical ecology of the settlement of benthic marine invertebrates. Oceanogr Mar Biol Annu Rev 30:273-335

Pechenik JA (1990) Delayed metamorphosis by larvae of benthic marine invertebrates: Does it occur? Is there a price to pay? Ophelia 32(1-2):63-94

Pechenik JA, Qian PY (1998) Onset and maintenance of metamorphic competence in the marine polychaete Hydroides elegans Haswell in response to three chemical cues. J Exp Mar Biol Ecol 226:51-74

Qian PY, Rittschof D, Sreedhar B (2000) Macrofouling in unidirectional flow: miniature pipes as experimental models for studying the interaction of flow and surface characteristics on the attachment of barnacle, bryozoan and polychaete larvae. Mar Ecol Prog Ser 207:109-121

Qian PY, Thiyagarajan V, Lau SCK, Cheung SCK (2003) Relationship between bacterial community profile in biofilm and attachment of the acorn barnacle Balanus amphitrite. Aquat Microb Ecol 33:225-237

Qiu JW, Qian PY (1997) Effects of food availability, larval source and culture method on larval development of Balanus amphitrite amphitrite Darwin: implications for experimental design. J Exp Mar Biol Ecol 217:47-61

Editorial responsibility: Howard Browman (Associate Editorin-Chief), Storebø, Norway
Raimondi PT, Keough MJ (1990) Behavioural variability in marine larvae. Aust J Ecol 15:427-443

Rumrill SS (1990) Natural mortality of marine invertebrate larvae. Ophelia 32:163-198

Shapiro SS, Wilk MB (1965) An analysis of variance test for normality (complete samples). Biometrika 52:591-611

Steinberg PD, Nys RD, Kjelleberg S (2002) Chemical cues for surface colonization. J Chem Ecol 28:1935-1951

Swain GW, Nelson WG, Preedeekanit S (1998) The influence of biofouling adhesion and biotic disturbance on the development of fouling communities on non-toxic surfaces. Biofouling 12(1-3):257-269

Szewzyk U, Holmstrøm C, Wrangstadh M, Samuelsson MO, Maki JS, Kjelleberg S (1991) Relevance of the exopolysaccharide of marine Pseudomonas sp. strain S9 for the attachment of Ciona intestinalis larvae. Mar Ecol Prog Ser 75:259-265

Thistle D (1981) Natural physical disturbance and communities of marine soft bottoms. Mar Ecol Prog Ser 6:223-228

Toonen RJ, Pawlik JR (2001) Settlement of the gregarious tube worm Hydroides dianthus (Polychaeta: Serpulidae). II. Testing the desperate larva hypothesis. Mar Ecol Prog Ser 224:115-131

Unabia CRC, Hadfield M (1999) Role of bacteria in larval settlement and metamorphosis of the polychaete Hydroides elegans. Mar Biol 133:55-64

Underwood AJ, Fairweather PG (1989) Supply-side ecology and benthic marine assemblages. Trends Ecol Evol 4(1): $16-20$

Vanaverbeke J, Martinez-Arbizu P, Dahms HU, Schminke HK (1997) The metazoan meiobenthos along a depth gradient in the Arctic Laptev Sea with special attention to nematode communities. Polar Biol 18:391-401

Watzin MC (1983) The effects of meiofauna on settling macrofauna: meiofauna may structure macrofaunal communities. Oecologia 59:163-166

Wieczorek SK, Todd CD (1998) Inhibition and facilitation of settlement of epifaunal marine invertebrate larvae by microbial biofilm cues. Biofouling 12:81-118

Wieczorek SK, Murray AWA, Todd CD (1996) Seasonal variation in the effects of hard substratum biofilming on settlement of marine invertebrate larvae. Biofouling 10(4): 309-330

Young CM, Chia FS (1981) Laboratory evidence for delay of metamorphosis of larval settlement in response to a dominant competitor. Int J Invertebr Reprod 3:221-226

Zajac RN, Whitlatch RB (2003) Community and populationlevel responses to disturbance in a sandflat community. J Exp Mar Biol Ecol 294:101-125

Zar JH (1999) Biostatistical analysis, 4th edn. Prentice Hall, Upper Saddle River, NJ

Submitted: November 9, 2004; Accepted: April 12, 2005

Proofs received from author(s): July 8, 2005 